\title{
Renin Release and Gene Expression in Intact Rat Kidney Microvessels and Single Cells
}

\author{
Allen D. Everett, * Robert M. Carey, ${ }^{\ddagger}$ Robert L. Chevalier," Michael J. Peach,” and R. Ariel Gomez* \\ With the technical assistance of Katalin M. Geary \\ Departments of ${ }^{*}$ Pediatrics, ${ }^{\ddagger}$ Internal Medicine, and ${ }^{\S}$ Pharmacology, University of Virginia \\ Health Sciences Center, Charlottesville, Virginia 22908
}

\begin{abstract}
To investigate whether newborn kidney microvessels and isolated single microvascular cells have the capacity to release renin and/or alter the expression of the renin gene in response to adenylate cyclase stimulation, newborn kidney microvessels were isolated and purified (95\%) using an iron perfusion/enzymatic digestion technique. Incubation of microvessels with either vehicle (control; C) or $1^{-5} \mathrm{M}$ forskolin (F) in media resulted in an increase in microvessel cAMP $(0.67 \pm 0.13$ vs. $22 \pm 4.6 \mathrm{pmol} / \mathrm{min}$ per $\mathrm{mg}$ protein $)(P<0.005)$ and renin released into the culture media $(1,026 \pm 98$ vs. $1,552 \pm 159 \mathrm{pg}$ angiotensin $\mathrm{I} / \mathrm{h}$ per $\mathrm{mg}$ protein) $(P=0.008)(C$ vs. F $)$. Renin mRNA levels in the newborn kidney microvessels increased 1.6-fold with forskolin treatment. Renin release by isolated, single microvascular cells (with or without forskolin) was assessed using the reverse hemolytic plaque assay. Forskolin administration resulted in an increase in the number of reninsecreting cells without changes in the amount of renin secreted by individual cells.

In conclusion, newborn kidney microvessels and isolated renin-releasing microvascular cells possess a functionally active adenylate cyclase whose short-term stimulation results in accumulation of cAMP, a significant increase in renin release, and an enhancement of renin gene expression. The increase in renin release is due to recruitment of microvascular cells secreting renin. Recruitment of hormone-secreting cells in response to stimuli may prove to be a mechanism of general biological importance shared by many endocrine cell types. ( $J$. Clin. Invest. 1990. 86:169-175.) Key words: renin • messenger RNA - microvessel • cAMP • reverse hemolytic plaque assay • recruitment
\end{abstract}

\section{Introduction}

During development of the rat metanephric kidney, renin is localized to the large arcuate and interlobular arteries in the

Address correspondence to Dr. R. Ariel Gomez, University of Virginia, Health Sciences Center, Department of Pediatrics, Box 386, Charlottesville, VA 22908.

This information was previously presented at the 43rd annual Fall Conference of The Council for High Blood Pressure Research (American Heart Association) and won the Marion Hypertension Research Fellowship award.

Received for publication 5 October 1989 and in revised form 24 January 1990.

J. Clin. Invest.

(c) The American Society for Clinical Investigation, Inc.

0021-9738/90/07/0169/07 \$2.00

Volume 86, July 1990, 169-175 fetus and shifts to the classical juxtaglomerular loci by the time of adulthood (1). Similar developmental changes in immunoreactive renin distribution have been demonstrated in the mouse (2), pig (3), and human embryo (4). Using in situ hybridization histochemistry and renin immunocytochemistry, we have demonstrated that renin is synthesized and stored in widespread renal vascular segments during maturation (5). In addition, immunoelectron microscopy studies have demonstrated renin in granules of developing juxtaglomerular cells (6). These studies suggest a renin secretory process in the developing kidney vasculature. Although a recent study demonstrated that renal cortical slices from fetal lambs release renin in response to isoproterenol (7), the mechanism(s) underlying the increase in renin secretion during ontogeny remains incompletely understood.

Whereas $3^{\prime}-5^{\prime}$ cAMP is considered to be an important second messenger for renin release $(8,9)$, it is not known whether developing kidney microvessels possess a functionally active adenylate cyclase (AC) $)^{1}$ or if intracellular levels of cAMP results in renin release. Renin release in response to activation of the AC-cAMP system may result from an increase in the number of cells that secrete renin, from an increase in the amount of renin secreted per cell, or both. Using the reverse hemolytic plaque assay (10), it is now possible to perform secretion studies at the single cell level $(11,12)$ and to identify (and enumerate) those cells that release renin under basal conditions and/or in response to stimulation. The present series of experiments were designed to determine whether newborn kidney microvessels are capable of releasing renin under basal conditions and in response to stimulation of adenylate cyclase, and to establish whether the increase in renin secretion observed results from an increase in the amount of renin secreted per cell and/or a recruitment of renin-releasing cells. In addition, since cAMP accumulation may modulate renin gene transcription $(13,14)$, the effect of increasing intracellular cAMP concentration on renin gene expression in intact microvessels also was investigated.

\section{Methods}

Microvessel isolation. 15 late-gestation Wistar-Kyoto rats (Charles River Breeding Laboratories, Inc., Wilmington, MA) were housed in the University of Virginia vivarium and maintained on standard rat chow (5012; Ralston Purina Co., St. Louis, MO) and tap water ad lib. throughout the study. After delivery, the newborn rats were kept and fed by their respective mothers until the day of the study.

For each experiment $(n=30)$ four rat pups on days 4-10 postnatal age were killed by decapitation into liquid nitrogen and perfused systemically through the heart with $3 \mathrm{ml}$ of a $5 \%(\mathrm{wt} / \mathrm{vol})$ iron oxide

1. Abbreviations used in this paper: $\mathrm{AC}$, adenylate cyclase; $\mathrm{AI}$, angiotensin I; LD, lactate dehydrogenase. 
solution (RPMI 1640 culture media [Gibco Laboratories, Grand Island, NY] and ferrous ferric oxide [black; Fisher Scientific Co., Pittsburgh, PA]). Kidneys were removed, the capsule and medulla were dissected, and the remaining cortical tissue was placed in $30 \mathrm{ml}$ of cold, oxygenated $\left(95 \% \mathrm{O}_{2}, 5 \% \mathrm{CO}_{2}\right)$ enzyme solution containing $0.5 \mathrm{mg} / \mathrm{ml}$ collagenase type I (Sigma Chemical Co., St. Louis, MO) in tissue culture medium (RPMI 1640). Kidney cortical tissue was minced with a sterile razor blade and the remaining tissue fragments were teased apart with forceps. The crude kidney cortex dispersion was incubated at $37^{\circ} \mathrm{C}$ in a shaker bath for $30-45 \mathrm{~min}$ with intermittent mixing. Microvessels were separated from the nonvascular portion of the homogenate with a powerful magnet. Glomeruli were separated from the microvessels by passing the microvessel suspension through a 20-gauge needle twice. This maneuver efficiently detached glomeruli from their respective afferent arterioles. The microvessel suspension was transferred to a 75- $\mu \mathrm{m}$ sieve (E-C Apparatus Corp., St. Petersburg, FL) and washed under a stream of cold RPMI 1640 culture medium $(20 \mathrm{ml})$. Microvessels were resuspended in $5 \mathrm{ml}$ of tissue culture medium and purity was determined by microscopic examination. Only microvessel preparations $>90 \%$ free of tubular contamination were used (less than five tubule fragments per $100-\mathrm{mm}$ petri dish). In addition, purity was assessed biochemically by spectrophotometrically assaying for alkaline phosphatase activity (15) in the crude avascular cortex from seven experiments and the microvessel fractions from nine experiments as a marker of tubular contamination (16).

Intact microvessel studies. Microvessels were suspended and equally divided between two $100-\mathrm{mm}$ petri dishes containing $10 \mathrm{ml}$ culture medium (RPMI 1640, 10\% fetal bovine calf serum, $100 \mathrm{U} / \mathrm{ml}$ penicillin $\mathrm{G}$, and $0.1 \mathrm{mg} / \mathrm{ml}$ streptomycin) (Sigma Chemical Co.) and incubated at $37^{\circ} \mathrm{C}$ in an atmosphere of $5 \% \mathrm{CO}_{2}, 95 \%$ air with controlled humidity for $3 \mathrm{~h}$. To one plate $10^{-5} \mathrm{M}$ forskolin $(8 \mu \mathrm{l})$ was added at $1-\mathrm{h}$ intervals for $3 \mathrm{~h}$. The second dish was used as a control with $8 \mu \mathrm{l}$ of $95 \%$ ethanol (vehicle) added as described above. As a measure of microvessel viability and stability, nonconcentrated medium was assayed for lactate dehydrogenase (LD) activity each hour after the method of Wroblewski and LaDue (17). Medium samples before addition of microvessels $(n=4)$ and from three control and six forskolin experiments were assayed and results expressed as mean \pm SEM. At the end of $3 \mathrm{~h}$ the medium was decanted from each plate, concentrated using centrifugation tubes (Amicon Corp., Danvers, MA), and processed for renin enzymatic activity determinations or immediately frozen in liquid nitrogen and stored at $-70^{\circ} \mathrm{C}$. Microvessels were removed from each plate with a rubber policeman and transferred to a sterile polyethylene tube, immediately frozen in liquid nitrogen and stored at $-70^{\circ} \mathrm{C}$ until assayed for cAMP concentration, or processed for renin mRNA determination as described below.

Medium renin content. Angiotensin I (AI) generation was measured by the radioimmunoassay method of Sealy and Laragh (18) using an excess of rat renin substrate. Concentrated medium samples were incubated at $37^{\circ} \mathrm{C}$, pH 6.5 , for $30 \mathrm{~min}$. Concentrations are expressed as nanograms of $\mathrm{AI} /$ hour per milligram of medium protein. Protein was determined by the method of Lowry et al. (19). Medium samples were assayed from 20 forskolin and control microvessel experiments with each sample measured in duplicate. Results were expressed as mean \pm SEM.

Microvessel cAMP content. Microvessels were homogenized in $2 \mathrm{ml}$ of cold $0.1 \mathrm{~N} \mathrm{HCl}$ and centrifuged at $5,000 \mathrm{~g}$ for $5 \mathrm{~min}$ at $4^{\circ} \mathrm{C} .0 .5-\mathrm{ml}$ aliquots of supernatant were acetylated by adding $10 \mu \mathrm{l}$ triethylamine and $5 \mu \mathrm{l}$ of acetic anhydride at room temperature. Samples were assayed for cAMP concentration by automated gammaflow radioimmunoassay as described by Harper and Brooker (20). Five forskolin and five control microvessel experiments were assayed for cAMP content with each sample measured in duplicate and the results expressed as mean \pm SEM.

Microvessel renin $m R N A$ determinations. Microvessel samples were pooled from eight experiments (33 animals) and repeated in two other independent groups of experiments. Microvessels were pooled since the total RNA recovery from newborn kidney microvessels was too low to be analyzed independently. Total RNA was extracted as previously described following the method of Chirgwin et al. (21). Total RNA samples were submitted to Northern blot analysis as previously described $(5,22)$, and hybridized by the method of Church and Gilbert (23) using a full-length (1.4 kb) rat renin cDNA (24) (gift of Dr. K. Lynch, University of Virginia, Charlottesville, VA) labeled with ${ }^{32} \mathrm{P}$ by nick translation as we previously described $(5,22)$. Renin mRNA was detected by autoradiography using an intensifying screen and quantified by densitometry using an Ultroscan XL laser densitometer (LKB Instruments, Inc., Bromma, Sweden). Each lane was scanned three times and the average absorbance units for each lane were determined. Multiple exposures of Kodak AR and RP film were made to determine linearity. As a control, total RNA samples also were hybridized to beta-actin cDNA prepared from a rat aorta cDNA library (a gift of Dr. Gary Owens and Marcie Corjay, University of Virginia).

Single cell studies. Release of renin by individual microvascular cells was determined in seven separate experiments by the reverse hemolytic plaque assay as previously described $(11,12)$. Freshly isolated microvessels were enzymatically dispersed (RPMI $1640,1 \mathrm{mg} / \mathrm{ml}$ collagenase, $0.125 \mathrm{mg} / \mathrm{ml}$ elastase type III, $250 \mu \mathrm{g} / \mathrm{ml}$ soybean trypsin inhibitor, and $3 \mathrm{mg} / \mathrm{ml} \mathrm{BSA}$; Sigma Chemical Co.) to single cells and counted with a hemocytometer. Cell viability was determined by trypan blue exclusion and was $>95 \%$. Dispersed microvessel cells at a concentration of $\sim 10^{7}$ cells $/ \mathrm{ml}$ were mixed with an equal volume staphylococcal protein A-conjugated sheep erythrocytes (12\% vol/ vol). A Cunningham chamber was prepared by placing a glass coverslip with double-sided tape at each end on a poly-L-lysine-coated microscope slide. Each chamber held $\sim 30 \mu$ l of solution. $30 \mu \mathrm{l}$ of cell suspension, containing $\sim 2.4 \times 10^{6}$ sheep erythrocytes and $1 \times 10^{5}$ microvessel cells, was pipetted underneath the coverslip by capillary action and the cells were allowed to attach for $\mathbf{3 0} \mathrm{min}$. After the cells had formed a lawn, $10^{-5} \mathrm{M}$ forskolin or vehicle (95\% ethanol) was added to each slide with rabbit anti-rat renin antibody (1:60 final concentration; generously provided by Dr. T. Inagami, Vanderbilt University, Nashville, TN) and incubated at $37^{\circ} \mathrm{C}$ for $2 \mathrm{~h}$. The high specificity and characterization of this antibody have been documented previously $(25,26)$. Complement from guinea pig serum was applied to each slide (1:60) and incubated for 15-25 min until areas of hemolysis or plaques were visible. Viability of plaque-forming cells was determined by trypan blue exclusion and the slides were fixed in $2 \%$ glutaraldehyde. Slides were stained $(0.05 \%$ azure II, $0.02 \%$ methylene blue, and $0.05 \%$ sodium borate in distilled water for $30 \mathrm{~s}$ ) and plaque number was determined by direct light microscopy. From seven experiments a minimum of three slides per experiment were counted and the results averaged for each experiment. Results are expressed as plaque number \pm SEM. Plaque diameters (a measure of the quantity of renin released per cell) were measured by microscopic examination using an ocular micrometer. The diameter of a total of 232 and 121 plaques were measured in the forskolin and control groups, respectively.

Statistical analysis. Results are expressed as mean \pm SEM and analyzed by the unpaired $t$ test or Wilcoxon ranked sum test. For comparisons of results obtained with the reverse hemolytic plaque assay, plaque diameter frequency distribution polygons were constructed and compared using chi-square analysis. Significance was defined as $P$ $<0.05$.

\section{Results}

With the described iron oxide perfusion technique, newborn kidney microvessels of high purity were obtained. Microscopic visualization demonstrated the microvessel preparation to be $>90 \%$ free of glomerular and tubular tissue. A low-power, light photomicrograph of a typical newborn kidney microvessel preparation is shown in Fig. 1, demonstrating iron oxidefilled arterioles free of glomerular and tubular tissue. In addition to visual inspection, alkaline phosphatase determinations 

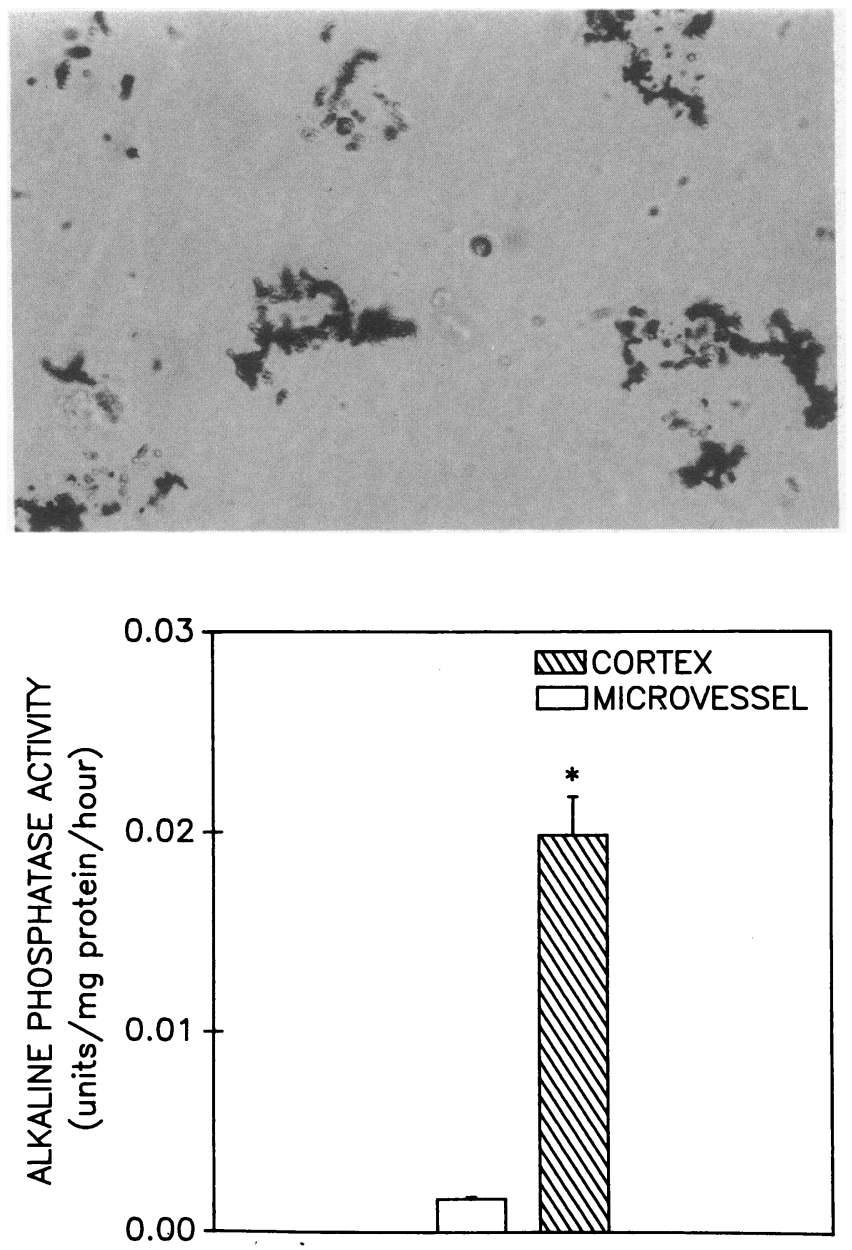

Figure 1. Top, Representative low power, light photomicrograph of newborn kidney microvessels. The isolated microarterioles appear as fine iron oxide-filled branching structures without evidence of glomerular or tubular tissue. $\times 25$. Bottom, Alkaline phosphatase activity in the avascular dispersed kidney cortex and the newborn kidney microvessels. For each experiment, microvessels or avascular cortex from eight kidneys (four rat pups) were isolated as described in the text. Cortex and microvessels from seven and nine experiments, respectively, were homogenized in normal saline and centrifuged at $5,000 \mathrm{~g}$, and the supernatant was assayed for alkaline phosphatase activity. Results are expressed as mean \pm SEM. ${ }^{*} P<0.008$.

were used as enzymatic markers of tubular tissue contamination. As demonstrated in Fig. 1, there was a > 10-fold enrichment in alkaline phosphatase activity in the cortex as compared with the microvessel fraction $(0.02 \pm 0.002 \mathrm{U} / \mathrm{mg}$ protein per h vs. $0.0017 \pm 0.0001 ; P<0.001$ ), reflecting the relative isolation of tubular tissue from the vessel fraction.

Effect of forskolin on cAMP accumulation and renin release. The effect of acute forskolin stimulation on intracellular cAMP accumulation and renin release from intact microvessels is shown in Fig. 2. Forskolin administration resulted in a significant increase in newborn kidney microvessel cAMP levels $(22.04 \pm 4.57$ vs. $0.667 \pm 0.13 \mathrm{pmol} / \mathrm{mg}$ protein; $n=5, P$ $<0.005)$ and in renin release into the medium $(1,551 \pm 159$ vs. $1,026 \pm 98 \mathrm{pg} / \mathrm{h}$ per $\mathrm{mg}$ protein; $n=20, P=0.008$ ).

Microvessel viability and stability were assured by LD determinations from the culture medium each hour of incuba-

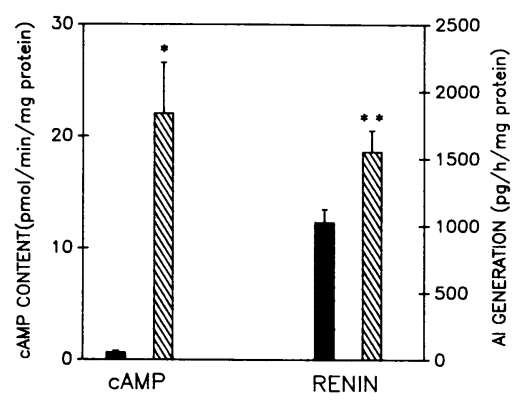

Figure 2. Microvessel cAMP concentration (cell associated) and renin released into the medium in response to forskolin administration. For each experiment, microvessels from eight kidneys (four rat pups) were isolated as described in the text and then equally di-

vided into control and forskolin treatment. Microvessels were assayed for cAMP content and the medium was assayed for renin content after $3 \mathrm{~h}$ of incubation (see text for details). Results are expressed as mean \pm SEM of 5 and 20 microvessel experiments for cAMP and renin determinations, respectively. ${ }^{*} P<0.005$; ${ }^{* *} P=0.008$.

tion. No significant elevation of LD activity occurred at the end of the 3-h study period in the time control (100 $\pm 11.5 \mathrm{LD}$ units/ml, $n=3$ ) or forskolin group ( $100 \pm 8.9 \mathrm{LD}$ units $/ \mathrm{ml}, n$ $=6)$ as compared with the medium alone before the addition of microvessels ( $120 \pm 11.5 \mathrm{LD}$ units/ml, $n=4)$.

Renin release from individual cells. To determine whether the increase in renin release associated with adenylate cyclase stimulation resulted from an increase in the amount of renin released per cell and/or the number of cells releasing renin, renin release by isolated, single newborn microvessel cells was determined using the reverse hemolytic plaque assay. Fig. 3 shows a photomicrograph of a typical plaque formed with a single renin-releasing cell in the center, surrounded by a ring of complement-mediated red cell hemolysis. As shown in Fig. 4, forskolin induced a significant increase $(41 \pm 9.5$ vs. $22 \pm 5.9$; $n$ $=7, P<0.05$ ) in the number of renin-releasing (plaque-forming) cells. Since renin release may be a heterogeneous process varying from cell to cell, to obtain a better understanding of the population; the distribution of renin-releasing cells was analyzed according to plaque size to estimate the quantity of renin released per cell. Fig. 5 shows a frequency distribution demonstrating the number of renin-releasing cells corresponding to different plaque diameters. As demonstrated, the population of renin-releasing microvascular cells, under basal conditions, is a heterogeneous group with a wide distribution of plaque diameters (mean $=15.4$, median $=13.6$, range $=30.6$, and variance $=45.5$ ), with the most frequent diameter (mode) being $10.2 \mu \mathrm{m}$. Forskolin administration significantly increased $(P<0.0001)$ the number of cells forming plaques at each diameter interval, although as the population statistics $($ mean $=15.8$, mode $=10.2$, median $=13.6$, range $=47.6$, and variance $=52.2$ ) and the curve in Fig. 5 demonstrate, the distribution of plaque diameters was not altered from the basal state. This result suggests that while forskolin increases the number of cells releasing renin, it does so by inducing a generalized increase in renin-releasing cells without favoring a particular cell subgroup. To confirm this hypothesis, a relative frequency distribution was constructed to determine if adenylate cyclase stimulation would alter the amount of renin released by each cell and thus result in an increase in the percentage of plaque diameters formed at a particular plaque diameter interval. As demonstrated in Fig. 6, the percentage of reninreleasing cells at any plaque diameter interval was not altered 


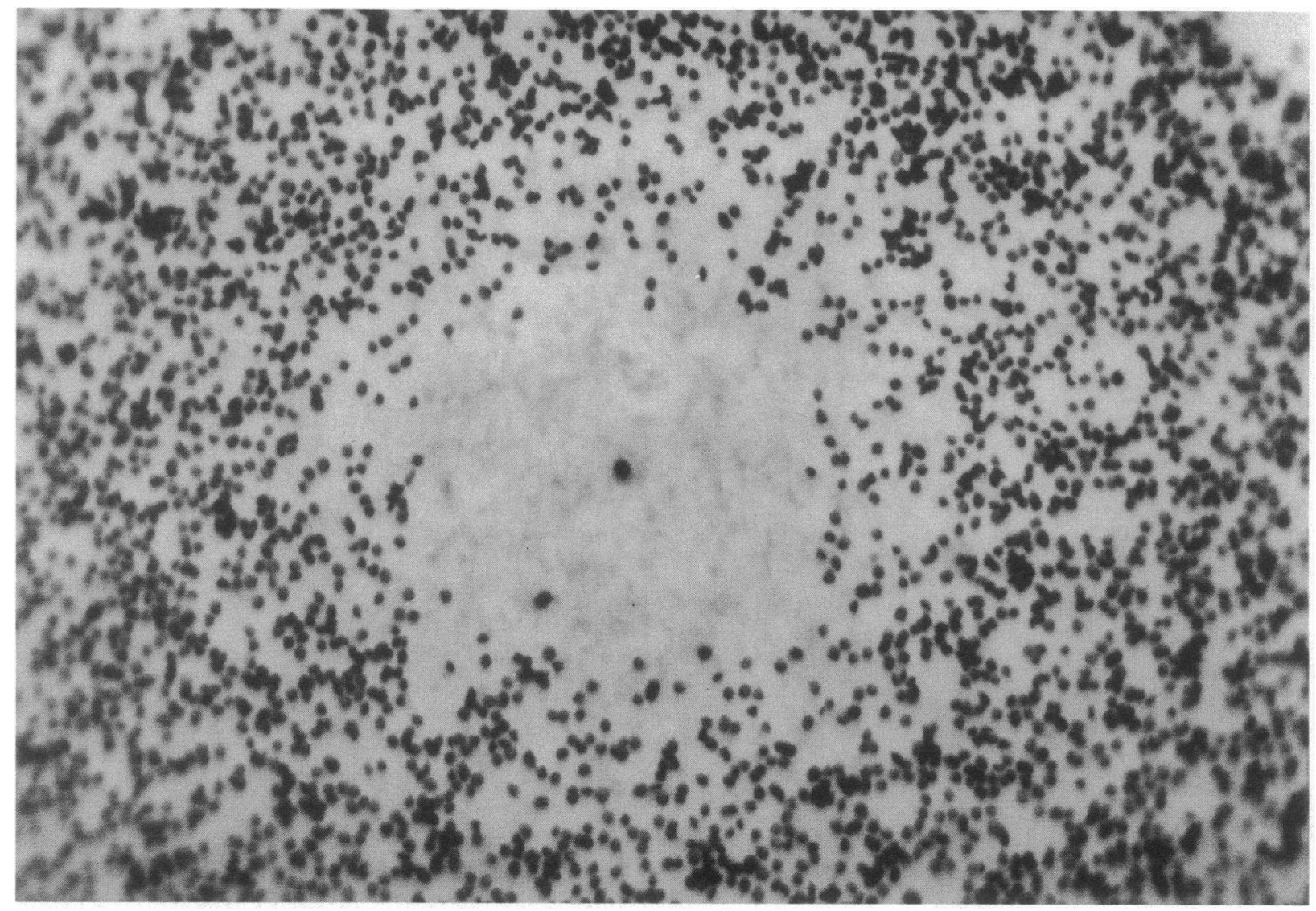

Figure 3. Reverse hemolytic plaque assay. For each experiment, freshly isolated microvessels obtained from eight kidneys (four rat pups) were dispersed into single cells $\left(10^{7} \mathrm{cells} / \mathrm{ml}\right)$ and mixed with protein A-conjugated sheep erythrocytes $(12 \% \mathrm{vol} / \mathrm{vol}) .30 \mu \mathrm{l}$ of the cell suspension was introduced into a Cunningham chamber and allowed to attach to a poly-L-lysine-coated slide. After the cells have formed a lawn, $10^{-5} \mathrm{M}$ forskolin or vehicle (control, 95\% ethanol) were added to each slide with renin antibody (1:60). After incubation for $2 \mathrm{~h}$, complement (1:60) was added and incubated until areas of hemolysis (plaques) were visible. Shown is a representative light photomicrograph of a single renin-releasing cell (center) with its associated halo of lysed sheep erythrocytes (plaque). $\times 125$.

from the basal state with forskolin administration $(P=0.427)$ as evidenced by the lack of shift in the plaque diameter distribution. Therefore, forskolin administration results in an increase in the overall number of renin-secreting cells without altering the overall amount of renin released by each cell.

Effect of forskolin on renin gene expression. The effect of treatment with forskolin on newborn kidney microvessel renin mRNA accumulation was studied using Northern blot analysis. The autoradiogram (Fig. 7) demonstrates a 1.6-fold increase in renin mRNA as compared with control. Similar re-

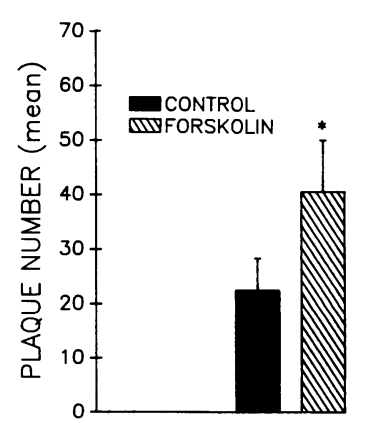

Figure 4. Effect of forskolin on number of renin-releasing cells. For each experiment, freshly isolated microvessels from eight kidneys (four rat pups) were dispersed into single cells and submitted to the reverse hemolytic plaque assay as described in Fig. 3 (see text for details). The number of renin-releasing cells (plaques) in response to forskolin or vehicle (control) were counted and compared between the two groups. The results from seven separate experiments are presented as mean \pm SEM. ${ }^{*} P<0.05$. sults (1.6-fold increase) were obtained in two separate experiments (data not shown). 5-d-old kidney total RNA was included as a positive control to confirm the appropriate electrophoretic mobility and molecular weight of the newborn

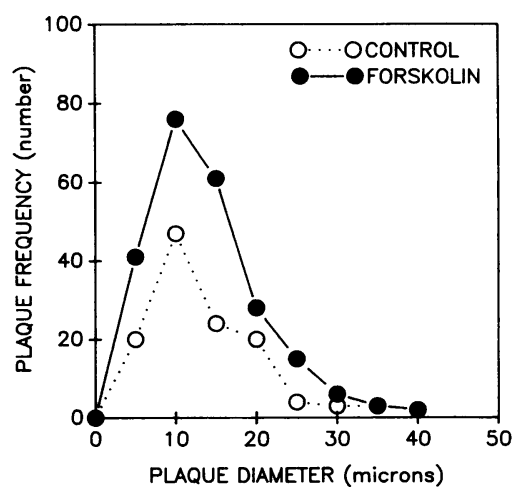

Figure 5. Relative frequency distribution showing the distribution of plaque diameters with forskolin and control treatments. From the seven experiments described in Fig. 4, a total of 232 and 121 plaques from forskolin and control experiments were measured. Abcissa, Plaque diameter intervals; ordinate, number of plaques cor-

responding to each plaque diameter interval. Chi-square analysis demonstrated that forskolin resulted in a significant $(P<0.0001)$ generalized increase in the number of cells secreting renin at every plaque diameter interval without significantly affecting plaque diameter. 


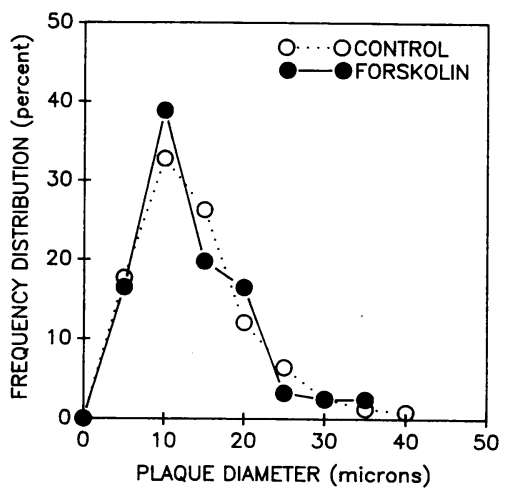

the total number of plaques formed within each group (control 121 or forskolin 232). Chi-square analysis showed that the percent of cells releasing renin at each plaque diameter interval were not significantly different $(P=0.427)$. Thus, forskolin results in an increase in the number of cells secreting renin without altering the amount of renin secreted per cell.

kidney microvessel renin mRNA (data not shown). Beta-actin mRNA levels were not altered by forskolin administration.

\section{Discussion}

This study demonstrates that isolated intact newborn rat kidney microvessels and single microvascular cells possess AC, and that stimulation of the cyclase results in a significant increase in renin release and an enhancement in renin gene expression. We also demonstrate that the increase in renin release is due to recruitment of renin-secreting cells and not to an increase in the amount of renin secreted per cell.

The diterpene compound, forskolin, is a direct (receptorindependent) stimulant of the catalytic subunit of adenylate cyclase (27). Stimulation of AC with forskolin in a number of cell systems rapidly increases intracellular concentrations of cAMP (27-29). Forskolin has been shown to induce renin release in isolated perfused adult rat kidneys $(30,31)$ and adult rat kidney slices (32). While AC in isolated adult rabbit kidney microvessels can be stimulated by parathyroid hormone fragments (33), the effect of forskolin and its relation to renin release has not been reported with renal microvessels or isolated cells at any age. In the present study, detection of basal levels of cAMP and stimulation of intact newborn kidney microvessels with forskolin provided evidence for an intact and active $A C$ in newborn renal microvascular cells. The accumu-

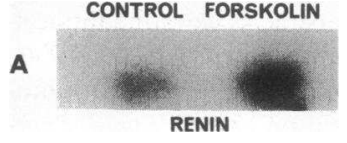

Figure 7. Newborn kidney microvessel renin gene expression with forskolin administration. Representative Northern blot analysis of total RNA forskolin-treated newborn kidney microvessels and control (vehicle treated $=95 \%$ ethanol treated) newborn kidney microvessels. Total microvessel RNA was pooled from 33 4-10-d-old Wistar-Kyoto rats. $5 \mu \mathrm{g}$ of total RNA was applied to each lane and hybridized to a ${ }^{32} \mathrm{P}$-labeled, full-length rat renin cDNA $(A)$ or beta-actin cDNA ( $B$ ). Exposure was $7 \mathrm{~d}$ at $-70^{\circ} \mathrm{C}$ (Kodak RP film) for $A$ and 3 $\mathrm{d}$ (Kodak AR film) for $B$, both with an intensifying screen. lation of intracellular cAMP was accompanied by a parallel increase in renin released into the medium, suggesting that renin release from newborn renal microvessels may be mediated by changes in the intracellular concentration of cAMP, as has been assumed from studies in the adult kidney (34). Since only two cell types are predominant in the preparation used in current studies, it seems likely that renin is released by a cAMP-dependent process.

The reverse hemolytic plaque assay provides a useful method for examining renin release at the single cell level. The results of the present study indicate that the population of renin-secreting cells is heterogeneous, with a wide range of renin secretory rates between individual cells. Although peptide-secreting pancreatic beta $(35,36)$, thyroid $(37)$, and hepatic cells (38) possess heterogeneous peptide synthetic and secretory capabilities, this heterogeneity had not been previously described for the renin-secreting cell. Stimulation of newborn kidney microvascular cells with forskolin resulted in a significant increase in the number of renin-releasing cells (hemolytic plaques) without a change in plaque size. These findings indicate that the CAMP-induced increase in renin release from developing kidney microvessels is achieved through recruitment of renin-releasing cells. We have recently observed a similar phenomenon in renal cells obtained from rats subjected to chronic inhibition of angiotensin converting enzyme (11). Thus, it appears that under the influence of certain stimuli, renin release is accomplished by an increase in the number of available renin secretory cells. Further studies are necessary to determine whether a similar response is obtained with other well-known stimuli for renin release. Taken together, these findings suggest that cell recruitment may be a general biological phenomenon shared by many different endocrine cells (35-38), which in turn may be important in the control of peptide hormone availability.

Pratt et al. (39) recently demonstrated in mouse cell lines transfected with the human renin gene that stimulation of renin release with 8-bromo-cAMP resulted in an increase in the release of active renin from storage granules without altering the constitutive release of prorenin. This is consistent with our results of increased secretion of active renin into the medium from newborn kidney microvessels in response to a forskolin-mediated increase in intracellular cAMP levels. However, the present study with isolated cells cannot address whether prorenin or active renin was secreted due to the fact that the antibody used in the reverse hemolytic plaque assay recognizes both forms of renin $(25,26)$. Acute administration of forskolin increased renin release from newborn kidney microvessels and was associated with a detectable increase in renin mRNA levels at $3 \mathrm{~h}$. In addition, renin mRNA did not appear degraded in the forskolin and control groups as betaactin mRNA levels were not altered. Dzau et al. (40) reported that acute isoproterenol administration in the adult mouse resulted in an immediate increase in plasma renin and cAMP levels, although kidney renin mRNA levels did not increase significantly for 6-8 h. Further studies on gene expression with forskolin over longer periods of time are currently in progress. Both studies do suggest that cAMP and/or secretion ultimately affect renin gene expression or turnover of mRNA in the adult and newborn animal.

In summary, isolated newborn kidney microvessels and individual microvascular cells possess a functionally active AC. Stimulation of AC for $3 \mathrm{~h}$ results in a significant increase 
in renin release and an enhancement in renin gene expression. Renin-releasing microvascular cells are a heterogenous population composed of cells with variable rates of renin secretion in the basal and stimulated states. We conclude that the cAMP-dependent increase in renin release is due to a recruitment of microvascular cells. Recruitment of hormone-secreting cells may prove to be a mechanism of general biological importance shared by many endocrine cells in the newborn as well as the adult animal.

\section{Acknowledgments}

We acknowledge the skillful assistance of Mary Hunt for renin enzymatic assays.

This work was supported by the American Heart Association Grant-In-Aid 86104 to R. A. Gomez and National Institutes of Health (NIH) grants R01 HL-41899 and IK04 HL-02307 (to R. A. Gomez). Dr. Chevalier is supported by NIH grants R01 HL-40209 and R01 DK-40558. Dr. Allen D. Everett is the recipient of an American Heart Association, Virginia Affiliate fellowship 880014. Dr. Gomez is the recipient of a Syntex Scholars Award from Syntex Corporation, which partially funded these studies.

\section{References}

1. Gomez, R. A., R. L. Chevalier, B. C. Sturgill, D. W. Johns, M. J. Peach, and R. M. Carey. 1986. Maturation of the intrarenal renin distribution in Wistar-Kyoto (WKY) rats. J. Hypertens. 4(Suppl 5):S31-S33

2. Minuth, M., E. Hackenthal, K. Poulsen, E. Rix, and R. Taugner. 1981. Renin immunocytochemistry of the differentiating juxtaglomerular apparatus. Anat. Embryol. 162:173-181.

3. Egerer, G., R. Taugner, and K. Tiedmann. 1984. Renin immunohistochemistry in the mesonephros and metanephros of the pig embryo. Histochemistry. 81:385-390.

4. Celio, M., P. Groscurth, and T. Inagami. 1985. Ontogeny of renin immunoreactive cells in the human kidney. Anat. Embryol. 173:149-155.

5. Gomez, R. A., K. R. Lynch, B. C. Sturgill, J. P..Elwood, R. L. Chevalier, R. M. Carey, and M. J. Peach. 1989. Distribution of renin mRNA and its protein in the developing kidney. Am. J. Physiol. 257(Renal Fluid Electrolyte Physiol. 26):F850-F858.

6. Lacasse, J., M. Ballak, C. Mercure, J. Gutkowska, C. Chapeau, S. Foote, J. Menard, P. Corvol, M. Cantin, and J. Genest. 1985. Immunocytochemical localization of renin in juxtaglomerular cells. J. Histochem. Cytochem. 33:323-332.

7. Nakamura, K. T., W. V. Page, T. Sato, J. M. Klinkefus, and J. E. Robillard. 1989. Ontogeny of isoproterenol-stimulated renin secretion from sheep renal cortical slices. Am. J. Physiol. 256:R1258-R1263.

8. Keeton, T. K., and W. B. Campbell. 1980. The pharmacological alteration of renin release. Pharmacol. Rev. 32:81-227.

9. Davis, J. O., and R. H. Freeman. 1976. Mechanisms regulating renin release. Physiol. Rev. 56:1-56.

10. Leong, D. A., S. K. Lau, Y. N. Sinha, D. L. Kaiser, and M. O. Thorner. 1985. Enumeration of lactotropes and somatotropes among male and female pituitary cells in culture: evidence in favor of a mammosomatotrope subpopulation in the rat. Endocrinology. 4:13711378.

11. Ice, K. S., K. M. Geary, R. A. Gomez, D. W. Johns, M. J. Peach, and R. M. Carey. 1988. Cell and molecular studies of renin secretion. Clin. Exp. Hypertens. Part A Theory Pract. A10:1 169-1 187

12. Johns, D. W., R. M. Carey, R. A. Gomez, K. Lynch, T. Ina- gami, J. Saye, K. Geary, D. E. Farnsworth, and M. J. Peach. 1987. Isolation of renin-rich rat kidney cells. Hypertension (Dallas). 10:488496.

13. Fukamizu, A., K. Nishi, T. Cho, M. Saitoh, K. Nakayama, H. Ohkubo, S. Nakanishi, and K. Murakami. 1988. Structure of the rat renin gene. J. Mol. Biol. 201:443-450.

14. Deutsch, P. J., J. P. Hoeffler, J. L. Jameson, J. C. Lin, and J. F. Habener. 1988. Structural determinants for transcriptional activation by cAMP-responsive DNA elements. J. Biol. Chem. 263:1846618472.

15. Tietz, N. W., and A. D. Rinker. 1983. Analytical Concepts in Enzymology. H. A. Homberger, editor. College of American Pathologists, Skokie, IL. 195-203.

16. Helwig, J. J., C. Mandel, and C. Bollack. 1974. Distribution of some phosphohydrolases in glomerular and tubular fractions isolated from rabbit kidney. Arch. Int. Physiol. Biochim. 82:907-916.

17. Wroblewski, F., and J. S. LaDue. 1955. Lactic dehydrogenase activity in blood. Proc. Soc. Exp. Biol. Med. 90:210-213.

18. Sealy, J. E., and J. H. Laragh. 1977. How to do a plasma renin assay. Cardiovasc. Med. 2:1079-1086.

19. Lowry, O. H., N. J. Rosebrough, A. L. Farr, and R. J. Randall. 1951. Protein measurement with the Folin phenol reagent. J. Biol. Chem. 193:265-275.

20. Harper, J. F., and G. Brooker. 1975. Femtomole sensitive radioimmunoassay for cyclic AMP and cyclic GMP after 2' 0 acetylation by acetic anhydride in aqueous solution. J. Cyclic Nucleotide Protein Phosphorylation Res. 1:207-218.

21. Chirgwin, J. M., A. E. Przbyla, R. J. MacDonald, and W. J. Rutter. 1979. Isolation of biologically active ribonucleic acid from sources enriched for ribonucleases. Biochemistry. 18:5294-5299.

22. Gomez, R. A., K. R. Lynch, R. L. Chevalier, N. Wilfong, A. Everett, R. M. Carey, and M. J. Peach. 1988. Renin and angiotensinogen gene expression in maturing rat kidney. Am. J. Physiol. 254:F582-F587.

23. Church, G. M., and W. Gilbert. 1984. Genomic sequencing. Proc. Natl. Acad. Sci. USA. 81:1991-1995.

24. Burnbaum, C. E., C. L. Hawelu-Johnson, B. M. Frank, and K. R. Lynch. 1987. Molecular cloning of rat renin $\mathrm{mRNA}$ and its gene. Proc. Natl. Acad. Sci. USA. 84:5605-5609.

25. Naruse, K., Y. Takii, and T. Inagami. 1981. Immunohistochemical localization of renin in luteinizing hormone-producing cells of rat pituitary. Proc. Natl. Acad. Sci. USA. 78:7579-7583.

26. Takii, Y., A. F. S. Figueiredo, and T. Inagami. 1985. Application of immunochemical methods to the identification and characterization of at kidney inactive renin. Hypertension (Dallas). 7:237-243.

27. Seamon, K. B., W. Padgett, and J. W. Daly. 1981. Forskolin: unique diterpene activator of adenylate cyclase in membranes and in intact cells. Proc. Natl. Acad. Sci. USA. 78:3363-3367.

28. Legrand, A. B., T. K. Narayanan, U. S. Ryan, R. S. Aronstam, and J. D. Catravas. 1989. Modulation of adenylate cyclase activity in cultured bovine pulmonary arterial endothelial cells: effects of adenosine and derivatives. Biochem. Pharmacol. 38:423-430.

29. Swanson, S. M., J. X. Jiang, Y. S. Chang, N. J. De Souza, and J. M. Pezzuto. 1988. A rapid and sensitive bioassay involving cultured rat glioma cells to screen for substances capable of elevating intracellular cyclic AMP concentration. J. Nat. Prod. (Lloydia). 51:929-936.

30. Schwertschlag, U., and E. Hackenthal. 1982. Forskolin stimulates renin release from the isolated perfused rat kidney. Eur. J. Pharmacol. 84:111-113.

31. Fray, J. C. S., and C. S. Park. 1986. Forskolin and calcium: interactions in the control of renin secretion and perfusate flow in the isolated rat kidney. J. Physiol. (Lond.). 375:361-375.

32. Park, C. S., D. H. Sigmon, D. S. Han, T. W. Honeyman, and J. C. S. Fray. 1986. Control of renin secretion by $\mathrm{Ca}^{2+}$ and cyclic AMP through two parallel mechanisms. Am. J. Physiol. 251:R531-R536.

33. Helwig, J. J., M. C. M. Yang, C. Bollack, C. Judes, and P. K. T. 
Pang. 1988. Response of isolated renal microvessel and tubule adenylate cyclases to PTH fragments. Kidney Int. 34:S45-S48.

34. Churchhill, P. C. 1985. Second messengers in renin secretion. Am. J. Physiol. 249:F175-F184.

35. Salomon, D., and P. Meda. 1986. Heterogeneity and contactdependent regulation of hormone secretion by individual beta cells. Exp. Cell Res. 162:507-520.

36. Schuit, F. C., P. A. In'T Veld, and D. G. Pipeleers. 1988 Glucose stimulates proinsulin biosynthesis by a dose-dependent recruitment of pancreatic beta cells. Proc. Natl. Acad. Sci. USA. 85:3865-3869.

37. Gerber, H., H. J. Peter, C. Bachmeier, J. Kaempf, and H. Studer. Progressive recruitment of follicular cells with graded secretory responsiveness during stimulation of the thyroid gland by thyrotropin. Endocrinology. 120:91-96.

38. Lin, C., W. Palmer, J. Wu, and L. Chan. 1986. Estrogen induction of very low density apolipoprotein II synthesis, a major avian liver yolk protein, involves the recruitment of hepatocytes. Endocrinology. 118:538-544.

39. Pratt, R. E., J. A. Flynn, P. M. Hobart, M. Paul, and V. J. Dzau. 1988. Different secretory pathways of renin from mouse cells transfected with the human renin gene. J. Biol. Chem. 263:3137-3141.

40. Dzau, V. J., J. E. Carlton, and T. Brody. 1987. Sequential changes in renin secretion-synthesis coupling in response to acute beta adrenergic stimulation. Clin. Res. 35:604a. (Abstr.) 